\title{
KOMODIFIKASI TARI KECAK DALAM SENI PERTUNJUKAN DI BALI (KAJIAN ESTETIKA HINDU)
}

\author{
Wayan Seriasih \\ STKIP Agama Hindu Singaraja, Singaraja, Indonesia \\ Email : seriasih123@gmail.com
}

\begin{abstract}
Abstrak
Tari Kecak adalah salah satu jenis kesenian tradisional dari Bali yang diciptakan pada kisaran tahun 1930 oleh seorang penari sekaligus seniman dari Bali yakni Wayan Limbak. Selain antusias masyarakat Bali terhadap seni garapan Wayan Limbak ternyata para wisatawan yang berkunjung ke Bali juga sangat tertarik dalam menyaksikan sebuah pertunjukan gerak seni ini. Tak heran jika pemerintah daerah setempat menjadikan tarian ini sebagai salah satu icon kesenian dan kebudayaan daerah. Tari tradisional Bali ini berfungsi sebagai sarana hiburan sekaligus usaha melestari kebudayaan Hindu di Bali. Dalam tarian ini hampir tidak ada alat musik pengiring kecuali suara gemerincing serta suara "cak-cak-cak-cak" dari para penari. Sendratari ini menceritakan tentang kisah Ramayana yakni peristiwa diculiknya Dewi Shinta oleh Rahwana hingga pembebasannya yang dilakukan oleh Rama beserta pasukannya. Secara estetis Tari Kecak dapat dilihat dalam setiap ritme gerakannya dan juga tempat pementasannya.
\end{abstract}

Kata Kunci : komodifikasi, tari kecak

\section{Pendahuluan}

Tari Kecak merupakan salah satu jenis tari tradisional di Bali yang sangat memukau para penonton. Keunikan dari gerakan serta kemistikan dalam pertunjukan membuat tarian ini sangat istimewa bagi kalangan wisatawan baik domestik maupun mancanegara yang menyaksikannya saat menyambangi Pulau Bali. Tak heran jika tarian yang diciptakan oleh Wayan Limbak ini sangat terkenal hingga ke mancanegara.

Tari Kecak adalah salah satu jenis kesenian tradisional dari Bali yang diciptakan pada kisaran tahun 1930 oleh seorang penari sekaligus seniman dari Bali yakni Wayan Limbak. Sebagai seorang seniman tentu saja Wayan Limbak sangat akrab dengan para seniman lain, sebut saja Walter Spies yang merupakan seorang pelukis dari negara Jerman merupakan salah satu teman akrab Wayan Limbak. Kedua sahabat inilah yang menjadi pencetus Tari Kecak yang sangat terkenal hingga saat ini. Tarian yang kerap dimainkan oleh laki-laki ini kini menjadi 
salah satu icon kebudayaan Bali yang cukup mendapat sanjungan oleh para wisatawan yang berkunjung ke Bali.

Meskipun gerakan yang dilakukan oleh para penari tergolong sangat sederhana, namun pembawaan para penari yang berjumlah cukup banyak mulai dari puluhan hingga ribuan orang membuat gerakan yang dimainkan tergolong sangat unik dan menarik. Pementasan dan pertunjukan tari tradisional dari Bali ini dapat dengan mudah disaksikan di beberapa wilayah Bali seperti Uluwatu, Garuda Wisnu Kencana, Ubud, dan Gianyar Bali. Ekspresi para penari nan memukau membuat para penonton tercengang akan penampilan mereka. Di lain sisi musik pengiring hampir tidak ada, hanya suara dan lantunan kata-kata yang berbunyi "cak-cak-cak-cak" terdengar dalam mengiringi gerakan tarian.

Jika menyaksikan Tari Kecak dari awal hingga akhir, maka tergambar alur cerita yang disajikan dari gerakan-gerakan pementasan oleh para penari. Antusias masyarakat Bali akan keberlangsungan dan kelestarian kesenian tradisional membuat banyak orang belajar dan tertarik untuk melakukan tarian yang diciptakan oleh Wayan Limbak ini. Tak heran jika hampir semua pemuda Bali khususnya para laki-laki mampu melakukan gerakan tarian ini dengan cara duduk melingkar. Para penari mengenakan pakaian khas bercorak kotak-kotak hitam putih mirip dengan papan catur. Dari tahun 1970 Tari Kecak terus mengalami peningkatan, bahkan pemerintah daerah setempat menjadikan tari ini sebagai icon budaya masyarakat Bali.

Estetika Hindu berasal dari kata Yunani aisthetika : hal-hal yang dapat diserap dengan panca indria, aisthesis : pencerapan indria atau sense perception. Baungarten, menulis aesthetic atau juga esthetic dan kemudian berangsur-angsur menggantikan semua sebutan filsafat, teori atau ilmu tentang keindahan tentang citrarasa atau seni (Djelantik,1999:2). Dalam Bahasa Indonesia dipergunakan istilah estetik dan bukan filsafat keindahan. Estetik adalah sebuah cabang ilmu yang menelaah tentang seni dan keindahan serta tanggapan manusia terhadapnya (Tim Penyusu, 2008:382). Kemudian perkembangan secara linguistik disebutkan dengan istilah estetika (Djelantik,1999:4). Secara umum konsep estetika Hindu di Bali dapat digolongkan menjadi tiga kelompok besar yang disebut tiga wisesa, yaitu

1. Satyam merupakan wujud atau bentuk dari kebenaran produk seni yang dihasilkan;

2. Siwam adalah proses atau wujud dari kesucian hasil produk seni;

3. Sundaram merupakan wujud dari produk seni yang dapat dinikmati dari sudut pandang keindahannya (Granoka,1998:15).

Konsep tiga wisesa ini dimaksudkan untuk mencapai ruang estetika metafisika. Sehingga mampu meneropong roh yang terhanyut oleh keindahan dalam bahasa Kawi atau Jawa Kuno disebut langö (Mardiwarsito, 1986: 310). Dengan objek ritual dan memiliki nilai magis. Sehingga perlu proses penyucian sang diri atau katharsis. Setelah proses penyucian ini unsur estetika akan masuk 
pada ruang kesunyian, sunya atau suwung. Akhirnya seni tersebut rohnya semakin bersatu dengan pemilik keindahan yang abadi atau Ida Sang Hyang Widhi Wasa (Granoka,1998:28). Yang dipentingkan dalam estetika Hindu adalah sebuah dialektika estetik yang selalu menempatkan kebenaran itu suci dan indah. Karena kesucian itu harus benar dan indah, serta keindahan itu harus suci dan mengandung kebenaran. Sehingga kebenaran yang ditampilkan demikian

\section{Sejarah Tari Kecak}

Tari Kecak merupakan tarian yang dicetuskan dan diciptakan oleh seniman asal Bali yakni Wayan Limbak dan seorang sahabatnya dari Jerman. Pada awal kemunculan nya jenis tari ini tercipta secara tidak sengaja yang diambil dari sebuah tarian adat pemujaan yang dikenal dengan sebutan Sanghyang. Sanghyang adalah jenis tarian tradisional Bali yang dilakukan dalam upacara religi seperti menolak bala serta mengusir suatu wabah penyakit. Dari sebuah pementasan Sanghyang inilah kemudian Wayang Limbak bersama Walter Spies berinovasi menciptakan sebuah gerakan tari sebagai salah satu wujud kecintaan mereka terhadap budaya dan kesenian Bali.

Salah satu jenis kesenian tari ini disajikan oleh para penari yang duduk melingkar serta mengucapkan kata "cak-cak-cak-cak" secara serentak, karena ini pula tarian ini diberi nama dengan sebutan "Tari Kecak". Gerakan tangan yang disajikan dalam pertunjukan sebenarnya mengisahkan sebuah cerita Ramayana yakni pada peristiwa Dewi Shinta diculik oleh Rahwana. Hingga akhir pertunjukan biasanya tari ini menyajikan kisah pembebasan Dewi Sintha dari tangan Rahwana.

Guna mendukung cerita yang disajikan maka dalam pertunjukan tari tradisional Bali juga harus terdapat beberapa tokoh yang memerankan peran utama sebagai Hanoman, Sugriwa, Dewi Shinta, Rhama, dan Rahwana. Pada tahun 70-an Wayan Limbak bekerja keras guna mempromosikan dan mengenalkan Tari Kecak hingga ke mancanegara. Selain mengenalkan keunikan dalam pementasan tarian ini tentu saja daerah asal kesenian ini ikut melambung di dunia Internasional yang kemudian menarik para wisatawan mancanegara untuk berkunjung ke Bali. Dalam perkembangannya pertunjukan tari yang juga menceritakan kisah pewayangan ini dimainkan oleh laki-laki yang berjumlah tak terbatas. Ada kalanya disajikan oleh puluhan orang namun dalam acara tertentu ada pula yang dipertunjukkan secara massal oleh ribuan penari.

Perkembangan tari kecak dari awal terciptanya hingga kini memang bisa dikatakan cukup membanggakan. Selain antusias masyarakat Bali terhadap seni garapan Wayan Limbak ternyata para wisatawan yang berkunjung ke Bali juga sangat tertarik dalam menyaksikan sebuah pertunjukan gerak seni ini. Tak heran jika pemerintah daerah setempat menjadikan tari kecak sebagai salah satu icon kesenian dan kebudayaan daerah. The Monkey Dance juga diberikan sebagai sebutan tari tradisional Bali yang satu ini. Hal ini diberikan karena salah satu adegan dalam pertunjukan tari tersebut menggunakan properti api serta tokoh utama yang berperan sebagai kera/ Hanoman. 


\section{Fungsi Tari Kecak}

Seperti telah tertuliskan di atas, Tari Kecak merupakan tarian yang berasal dari kreasi upacara sanghyang. Karena upacara sanghyang merupakan jenis kegiatan sakral dan hanya boleh dilakukan di Pura maka Wayan Limbak berinovasi dari inspirasi gerakan sanghyang menjadi gerakan tari yang terkenal hingga ke mancanegara. Adapun fungsi tari kecak dapat kita kelompokan secara garis besar sebagai berikut.

\section{Sebagai sarana hiburan}

Penciptaan gerakan tarian ini secara sadar dilakukan guna mempertunjukkan suatu kesenian khas bali pada masyarakat umum. Tarian ini bertujuan sebagai sarana hiburan baik bagi masyarakat setempat maupun bagi para wisatawan yang berdatangan ke Bali.

\section{Usaha melestarikan kebudayaan}

Dalam tarian yang berawal dari upacara Sanghyang ini juga terdapat kisah dan cerita yang tersirat dari awal hingga akhir pertunjukan. Cerita pewayangan yang di angkat dalam sebuah gerakan tari merupakan inovasi baru dalam usaha melestarikan kebudayaan Hindu khususnya dalam kisah Ramayana.

\section{Alat Musik Pengiring}

Hampir tidak ada alat musik pengiring tari kecak kecuali suara gemerincing serta suara dari para penari yang berbunyi "cak-cak-cak-cak". Meskipun tidak ada alat musik khusus sebagaimana tarian lain namun justru disini letak keunikan tari tersebut. Suara yang bersahut-sahutan dan kadang kala kompak membuat nadanada unik yang sangat menarik utuk didengarkan seiring gerakan tarian yang dilakukan oleh para penari. Suara gemerincing terdengar dari properti tari yang dikenakan oleh para penari khusunya tokoh utama dalam seni pertunjukan khas Bali tersebut.

\section{Properti Tari Kecak}

Sama halnya dengan tari serampang dua belas dan tari gambyong surakarta, tari kecak juga memiliki properti khas yang menjadi ciri khas dalam sebuah pertunjukan kesenian tradisional. Adapun properti yang biasa digunakan dalam pertunjukan antara lain sebagai berikut:

\section{Selendang}

Selendang atau kain yang dikenakan oleh para penari Tari Kecak memiliki corak kotak-kotak dengan warna hitam putih menyerupai papan catur. 


\section{Gelang kincringan}

Properti ini dikenakan baik pada pergelangan tangan dan sebagian juga pada pergelangan kaki. Gelang kicringan ini yang menimbulkan bunyi gemerincing pada saat gerakan tari dilakukan.

\section{Tempat sesaji}

Adanya tempat sesaji sebagai properti tari kecak menjadikan tarian ini sangat unik dan terlihat sakral. Terlebih asal usul gerakan tari yang berasal dari sebuah upacara adat Sanghyang membuat tarian ini juga terlihat mistis dikalangan para penonton.

\section{Topeng}

Minimal terdapat 3 topeng yang dikenakan oleh penari utama yang berperan sebagai tokoh Hanoman, Sugriwa, dan Rahwana pada cerita yang disajikan selama tarian berlangsung.

\section{Keunikan Tari Kecak}

Secara garis besar dalam seni pertunjukan Tari Kecak terdapat beberapa keunikan, keunikan tersebut antara lain terdapat pada:

\section{Gerakan}

Gerakan tarian yang ada dalam sebuah pertunjukan baik di Garuda Wisnu Kencana (GWK), Ubud, maupun tempat lain terlihat seperti seseorang yang tengah melakukan suatu pemujaan pada upacara Sanghyang.

\section{Musik pengiring}

Musik pengiring dalam tari kecak memang tergolong sangat unik. Karena hampir tidak ada alat musik yang dimainkan guna mengiringi pertunjukan. Musik yang terdengar pada sajian tarian khas dari Bali yang satu ini hanya terdengar dari gemerincing gelang grincingan yang dikenakan oleh para penari. Sementara suara lain hanya bersumber dari mulut para penari yang seolah saling bersahutan mengucapkan "cak-cak-cak-ke-cak-cak-cak".

\section{Drama}

Drama yang dimainkan dalam pementasan merupakan cerita Ramayana yang mengisahkan usaha pembebasan Dewi Shinta dari tangan Rahwana yang dilakukan oleh Rama dan beberapa sahabatnya. Cerita dalam tarian sebagaimana telah kita sebutkan di atas, pertunjukan Tari Kecak yang berfungsi sebagai usaha melestarikan kebudayaan disini alur cerita yang disajikan dalam suatu pementasan biasanya berupa kisah diculiknya Dewi Shinta oleh Rahwana, dan usaha Rama dalam membebaskan Dewi Shinta dari tangan Rahwana. Secara garis besar terdapat 5 bagian cerita yang mengisahkan demikian: 


\section{Bagian 1}

Menceritakan tentang keberadaan Rama dan Dewi Shinta di dalam hutan yang kemudian disusul kemunculan kijang emas. Dalam akhir cerita bagian 1 ini Shinta berhasil diculik oleh Rahwana dan dibawa ke Alengka yang menjadi kerajaan Rahwana.

\section{Bagian 2}

Pada bagian kedua ini Dewi Shinta ditawan di lingkungan kerajaan Alengka dengan dijaga Trijata yang merupakan keponakan dari Rahwana. Dalam adegan ini terlihat Shita bersedih hati akan peristiwa yang tengah menimpanya serta sangat berharap kedatangan Rama membebaskan dirinya dari Rahwana. Pada bagian ini pula Hanoman muncul sebagai utusan Rama dan mengisyaratkan kepada Dewi Shinta bahwa Rama akan datang dan menyelamatkan dirinya. Pada akhir bagian kedua ini Hanoman mempora-porandakan bangunan keraton Alengka dengan membakar beberapa bangunan keraton serta taman.

\section{Bagian 3}

Mengisahkan tentang kedatangan Rama ke negeri Alengka dengan bala tentaranya untuk membebaskan Dewi Shinta dari sekapan Rahwana. Pada awal pertempuran pihak Rama mengalami kekalahan melawan pasukan Rahwana. Setelah memanjatkan doa kepada Sang Dewa datanglah burung garuda menyelamatkan Rama dari pengaruh sihir yang dilakukan oleh keturunan Rahwana.

\section{Bagian 4}

Pertempuran antara Rama dan Rahwana kembali terjadi dan semakin seru. Pada bagian ini Sugriwa yang diperintahkan Raja Rama berhasil mengalahkan Megananda.

\section{Bagian 5}

Merupakan pucak dari pertunjukan tari kecak dimana menceritakan tentang kemenangan Rama atas Rahwana sehingga berhasil menemukan Dewi Shinta dan membebaskannya dari Rahwana. Cerita diakhiri dengan bertemunya kembali Rama dan Dewi Shinta serta beberapa pasukan pihak Rama seperti Hanoman dan Sugriwa.

\section{Estetika Tempat}

Metode pendekatan agama Hindu dalam upaya pembuktian atas suatu kebenaran, ada beberapa cara, tetapi metode pembuktian kebenaran yang dianggap paling sederhana adalah Tri Pramana atau tiga cara pembuktian, yaitu

1. agama pramana atau pendekatan teks dan otoritas,

2. anumana pramana atau pendekatan logika, analogi, akal, atau rasio; dan 
3. praktyaksa pramana atau uji klinis, pendekatan paktek dan praktis, dapat juga dianggap sebagai uji laboratorium dan laboratorium bagi agama Hindu adalah alam semesta (Pudja,1998:15).

Umat Hindu memandang bahwa segala gerak aktifitas yang dilakukan dengan ketulusan adalah sebuah persembahan. Tempat pementasan dari tarian kecak dirancang khusus agar memiliki nilai estetis tinggi bila ditonton oleh para wisatawan. Sebut saja misalnya tempat pementasan yang dilakukan di Pura Uluwatu, dipilih tempat yang memiliki view bagus serta tempat yang dibuat agar memudahkan para penonton untuk menikmati tarian tersebut. Sehingga akan mampu menambah nilai estetis dari pemetasan Tari Kecak tersebut.

\section{Estetika Gerak}

Secara alamiah manusia adalah wujud estetik itu sendiri, bukti impirik dari manusia sebagai mahluk estetik adalah adanya bentuk tubuh manusia yang seluruhnya mengandung unsur keindahan selain unsur fungsional. Ukuran proporsi tubuh manusia, antara panjang kakinya, panjang tangannya, lebar dadanya, bentuk mulut, mata, kuping, gigi, dan sebagainya merupakan wujud estetik ciptaan Ida Sang Hyang Widhi Wasa. Jika terdapat manusi dengan ukuranukuran yang tidak proporsional, maka orang cenderung menilainya sebagai seorang yang cacat dan otomatis tidak (kurang) estetis. Manusia sebagai mahluk estetis juga secara alamiah selalu ingin mengekspresikan naluri estetisnya

Puncak kreativitas manusia dalam mewujudkan estetikanya adalah manakala manusia hendak mewujudkan bentuk imannya kepada Ida Sang Hyang Widhi Wasa. Itulah sebabnya karya-karya estetik yang dijiwai oleh jiwa agama akan menghasilkan karya estetik yang agung tiada taranya dan tidak ditelan oleh waktu. Di Bali hampir semua aktivitas kehidupan menghasilkan karya estetik yang mendapatkan sentuhan napas agama, sehingga dunia mengakui bahwa karyakarya seni di Bali memiliki aura spiritual tersendiri atau metaksu.

Gerakan tarian yang ada dalam sebuah pertunjukan baik di Garuda Wisnu Kencana (GWK), Ubud, maupun tempat lain terlihat seperti seseorang yang tengah melakukan suatu pemujaan pada upacara Sanghyang. Hampir tidak ada alat musik pengiring tari kecak kecuali suara gemerincing serta suara dari para penari yang berbunyi "cak-cak-cak-cak". Meskipun tidak ada alat musik khusus sebagaimana tarian lain namun justru disini letak keunikan tari tersebut. Suara yang bersahut-sahutan dan kadang kala kompak membuat nada-nada unik yang sangat menarik utuk didengarkan seiring gerakan tarian yang dilakukan oleh para penari. Suara gemerincing terdengar dari properti tari yang dikenakan oleh para penari khusunya tokoh utama dalam seni pertunjukan khas Bali tersebut 


\section{Simpulan dan Saran}

\section{Simpulan}

Pengertian Tari kecak adalah salah satu jenis kesenian tradisional dari Bali yang diciptakan pada kisaran tahun 1930 oleh seorang penari sekaligus seniman dari Bali yakni Wayan Limbak. Selain antusias masyarakat Bali terhadap seni garapan Wayan Limbak ternyata para wisatawan yang berkunjung ke Bali juga sangat tertarik dalam menyaksikan sebuah pertunjukan gerak seni ini. Tak heran jika pemerintah daerah setempat menjadikan tarian ini sebagai salah satu icon kesenian dan kebudayaan daerah. Tari tradisional Bali ini berfungsi sebagai sarana hiburan sekaligus usaha melestari kebudayaan Hindu di Bali. Dalam tarian ini hampir tidak ada alat musik pengiring kecuali suara gemerincing serta suara "cak-cak-cak-cak" dari para penari. Adapun properti yang digunakan dalam tarian ini antara lain kain kotak-kotak, topeng, gelang kicringan, serta tempat sesaji. Sendra tari ini menceritakan tentang kisah Ramayana yakni peristiwa diculiknya Dewi Shinta oleh Rahwana hingga pembebasannya yang dilakukan oleh Rama beserta pasukannya. Secara estetis Tari Kecak dapat dilihat dalam setiap ritme gerakannya dan juga tempat pementasannya.

\section{DAFTAR PUSTAKA}

Bandem, I Made. 1996. Tari Bali. Yogyakarta: Kanisius.

Dibia, I Wayan. 2012. Teori Estetika Indonesia. Bahan Kuliah Program Doktor (S3) Kajian Budaya. Denpasar : Pascasarjana Kajian Budaya UNUD.

Djelantik, A.A. Made.1999. Estetika Sebuah Pengantar. Bandung : Masyarakat Seni Pertujukan Indonesia.

Granoka, Ida Wayan Oka.1998. Memori Bajra Sandhi. Perburuan Ke Prana Jiwa. Perburuan Seorang Ida Wayan Granoka. Denpasar: Sanggar Bajra Sandhi Bekerja sama dengan PT Seraya Bali Style.

Walter Spies.com - This wayTemplat:Clarifyme Walter Spies could study the Kecak and invented a way to transcribe it to paper. 